Vol. 22, No. 3 March 1998

ISSN 0955-6036

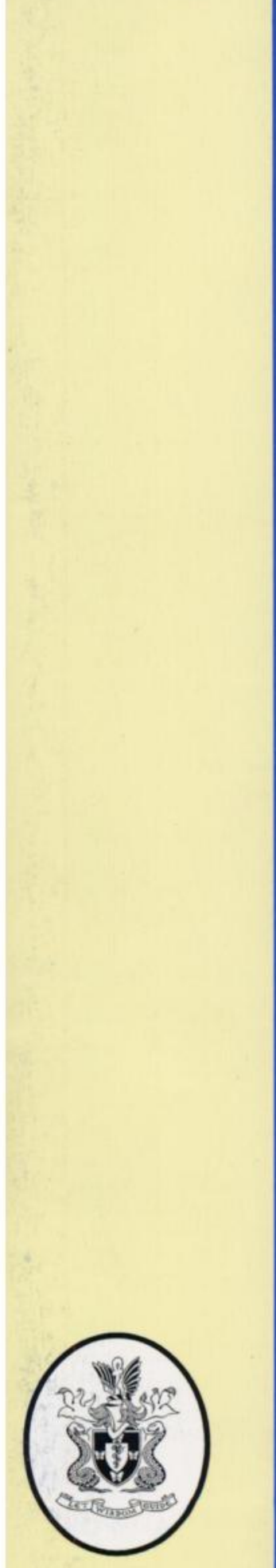

Royal College of Psychiatrists
Psychiatric Bulletin

The Journal of Trends in Psychiatric Practice 


\title{
Psychiatric Bulletin
}

\section{The Journal of Trends in Psychiatric Practice}

\author{
Editor: Dr Alan Kerr \\ Editorial Board: Dr Derek Chiswick, Dr Tom Fahy, \\ Dr Gyles Glover, Dr Louise Howard, Dr Peter Kennedy, \\ Dr Rosalind Ramsay, Dr Henry Rollin, Dr Mike Shooter, Dr David Tait, \\ Professor Peter Tyrer, Professor Greg Wilkinson \\ Bulletin Coordinator: Julia Burnside \\ Assistant Scientific Editor: Lucretia King Bulletin Assistant: Rachel Gold
}

\section{Notice to contributors}

The Psychiatric Bulletin concentrates on provision of services to people with mental disorders, and psychiatric training. It operates an independent peer review system.

Please send three copies of all submissions, typed double-spaced with wide margins. A good length is 1200 words. Key references must be listed using the Harvard system, as in the British Joumal of Psychiatry. A summary of up to 100 words should be supplied with original articles.

Submissions to the audit section should demonstrate a completed audit cycle and must be preceded by a structured abstract of up to 100 words. Correspondence on subjects of topical interest is welcome; letters should be no more than $\mathbf{3 5 0}$ words, with up to three references, and should not include diagrams or tables.

If an individual patient is described, his or her consent should be obtained, and the patient should read the report before submission. Where the patient is not able to give informed consent. it should be obtained from an authorised person. If consent is refused, a case study can only be written up if all personal details, dates and other identifying information are omitted to ensure that there is no breach of confidentiality. Contributors should be aware of the risk of complaint by patients in respect of defamation and breach of confidentiality.

All material submitted should be accompanied by a covering letter to the editor signed by all authors. Contributions are accepted for publication on the condition that their substance has not been published or submitted elsewhere.

The Psychiatric Bulletin is published monthly by the Royal College of Psychiatrists, 17 Belgrave Square, London SW1X 8PG. (Registered charity no. 228636.)

\section{Subcariptions}

Non-members of the College should contact the Publications Subscriptions Department, Royal Society of Medicine Press Limited, 1 Wimpole Street, London W1M 8AE (tel. 0171290 2928).

Subscription rate for 1998: $£ 52$ (UK and elsewhere), \$77 (USA).

The paper used in this publication meets the minimum requirements of American National Standard for Information Sciences - Permanence of Paper for Printed Library Materials. ANS1 Z39. 48-1984.

Psychiatric Bulletin is covered by the Excerpta Medica database EMBASE.

US Mailing Information: The Psychiatric Bulletin is published monthly by the Royal College of Psychiatrists. Subscription price is \$77. Second Class postage paid at Rahway, NJ. Postmaster send address corrections to Psychiatric Bulletin. c/o Mercury Airfreight International Ltd Inc., 2323 Randolph Avenue, Avenel, New Jersey 07001. ISSN 0955-6036.

Printed in Great Britain by Henry Ling Ltd, at the Dorset Press, Dorchester, Dorset.

Information about the College's publications is avallable on the World Wide Web at http:// www.rcpsych.ac.uk. Correspondence may be e-mailed to jburnside@rcpsych.ac.uk

C) 1898 The Rogal College of Pujchiatriets. Uniess so stated, material in the Psychiatric Bulletin does not necessarily reflect the views of the editor or the College. The publishers are not responsible for any error of omission or fact. 